\title{
Chitosan improves the chemical composition, microbiological quality, and aerobic stability of sugarcane silage
}

\author{
J.R. Gandra ${ }^{\mathrm{a}, *}$, E.R. Oliveira ${ }^{\mathrm{a}}$, C.S. Takiya ${ }^{\mathrm{c}}$, R.H.T.B. Goes ${ }^{\mathrm{a}}$, P.G. Paiva ${ }^{\mathrm{d}}$, \\ K.M.P. Oliveira ${ }^{\text {b }}$, E.R.S. Gandra ${ }^{\text {a }}$, N.D. Orbach ${ }^{\mathrm{a}}$, H.M.C. Haraki ${ }^{\mathrm{a}}$ \\ a Department of Animal Science, Universidade Federal da Grande Dourados, Rodovia Dourados-Itahum, km 12, Zip Code: 79804-970, \\ Dourados, MS, Brazil \\ b Department of Biology, Universidade Federal da Grande Dourados, Rodovia Dourados-Itahum, km 12, Zip Code: 79804-970, Dourados, \\ MS, Brazil \\ ${ }^{\mathrm{c}}$ Department of Animal Nutrition and Production, School of Veterinary Medicine and Animal Science, University of São Paulo (USP), Av. \\ Duque de Caxias Norte, 225-Campus da USP, Zip Code: 13635-900, Pirassununga, SP, Brazil \\ d Department of Animal Sciences, UNESP - Universidade Estadual Paulista “Júlio de Mesquita Filho"/Campus Jaboticabal, Rod. Prof. \\ Paulo Donato Castellane km 5, Rural, Zip Code: 14884-900, Jaboticabal, SP, Brazil
}

\section{A R T I C L E I N F O}

\section{Article history:}

Received 12 August 2015

Received in revised form 23 February 2016

Accepted 26 February 2016

\section{Keywords:}

Aerobic stability

Bacillus subtilis

Chitin

Fermentation

Inoculant

Lactobacillus buchneri

\begin{abstract}
A B S T R A C T
The purpose of the current study was to evaluate the effects of inoculants on chemical composition, dry matter (DM) and neutral detergent fiber (aNDF) in vitro degradation, fermentative and effluent losses, microbiology, fermentative profile, and aerobic stability of sugarcane mini-silos. Treatments were randomly distributed to the mini-silos, in which: (1) Control (CON); (2) Lactobacillus buchneri (Lb), addition of Lb at $2.6 \times 10^{10} \mathrm{cfu} / \mathrm{g}$; (3) Lactobacillus buchneri and Bacillus subtilis ( $\mathrm{Lb}+\mathrm{Bs}$ ), addition of $\mathrm{Lb}$ at $2.6 \times 10^{10} \mathrm{cfu} / \mathrm{g}$ and $\mathrm{Bs}$ at $1 \times 10^{9} \mathrm{cfu} / \mathrm{g}$; and (4) Chitosan (CHI), addition of $1 \%$ of $\mathrm{CHI}$ on wet basis of sugarcane ensiled. Treatments 2 and 3 were incorporated to the silage at $2 \mathrm{~g} / \mathrm{t}$ of natural matter ensiled. $\mathrm{Lb}$ and $\mathrm{Lb}+\mathrm{Bs}$ did not alter the in vitro degradation of DM and NDF. Chitosan incorporation increased the DM content $(P=0.013,18.7 \mathrm{~g} / \mathrm{kg} \mathrm{DM})$ and improved $(P=0.029$, $45.6 \mathrm{~g} / \mathrm{kg} \mathrm{DM})$ the NDF in vitro degradation of sugarcane silage. In addition, $\mathrm{CHI}$ incorporation showed higher $(P=0.002) \mathrm{DM}$ content in silage than $\mathrm{Lb}$ and $\mathrm{Lb}+\mathrm{Bs}$. Microbial inoculants $(\mathrm{Lb}$ and $\mathrm{Lb}+\mathrm{Bs})$ reduced the total losses $(P=0.009)$ of sugarcane silage. Moreover, $\mathrm{CHI}$ incorporation showed lower $(P=0.001,84.9 \mathrm{~g} / \mathrm{kg} \mathrm{DM})$ total losses and higher $(P=0.031,84.8 \mathrm{~g} / \mathrm{kg} \mathrm{DM})$ dry matter recovery than $\mathrm{Lb}$ and $\mathrm{Lb}+\mathrm{Bs}$. Lactic acid bacteria concentration was increased $(P=0.001)$ with additives, and $\mathrm{CHI}$ incorporation showed higher $(P=0.001)$ lactic acid bacteria concentration than silages treated $\mathrm{Lb}$ and $\mathrm{Lb}+\mathrm{Bs}$. All additives decreased the ethanol concentration in sugarcane silage, but $\mathrm{CHI}$ showed lower $(P=0.002)$ ethanol concentration compared to $\mathrm{Lb}$ and $\mathrm{Lb}+\mathrm{Bs}$. Inoculants improved the aerobic stability of sugarcane silage. In general, the incorporation of $\mathrm{CHI}$ to sugarcane silage showed better results of NDF in vitro degradation and gas and effluent losses than $\mathrm{Lb}$ and $\mathrm{Lb}+\mathrm{Bs}$. Moreover,
\end{abstract}

Abbreviations: aADF, acid detergent fiber; aNDF, neutral detergent fiber; Bs, Bacillus subtilis; CHI, chitosan; CON, control; CP, crude protein; DM, dry matter; DMR, dry matter recovery; Lb, Lactobacillus buchneri; TDN, total digestible nutrient.

* Corresponding author.

E-mail addresses: jeffersongandra@ufgd.edu.br(J.R. Gandra), caio.takiya@usp.br (C.S. Takiya), bocazoo@hotmail.com (P.G. Paiva). 
$\mathrm{CHI}$ incorporation showed higher concentration of lactic acid bacteria and lower concentration of ethanol compared to silages treated $\mathrm{Lb}$ and $\mathrm{Lb}+\mathrm{Bs}$. Chitosan may be an alternative additive to microbial inoculants used in sugarcane ensiling.

Published by Elsevier B.V.

\section{Introduction}

Sugarcane (Saccharum officinarum) is often used in Brazil as a forage source for dairy and beef cattle, since the harvesting phase coincides with the winter which is a period of shortage of feed. Ensiling sugarcane may be a strategy to decrease daily manpower and theoretically maintain similar nutrient composition from the beginning until the end of the silo. Sugarcane crop has a high DM production per hectare (25-40 t; Ávila et al., 2009), high water-soluble carbohydrates content, and a low buffering capacity that enables rapid decrease of $\mathrm{pH}$ (Freitas et al., 2006). However, its fermentation can produce high amounts of ethanol, increasing DM losses (Kung and Stanley, 1982), and accumulating fiber components causing a decrease of DM digestibility (Santos et al., 2009); thus, the advantages of ensiling sugarcane may be limited by these factors.

Microbial inoculants have been used to shift alcoholic fermentation and improve sugarcane silage digestibility. Several studies have evaluated Lactobacillus buchneri as a silage additive during the last decade (Santos et al., 2015; Carvalho et al., 2012; Pedroso et al., 2010). This heterolactic bacteria has been shown to improve silage fermentation due to a reduction of ethanol production and pH values (Pedroso et al., 2008). Kleinschmidt and Kung (2006) evaluated forty-three experiments and reported the effectiveness of $L$. buchneri to reduce the $\mathrm{pH}$ and yeast population, and its effectiveness to increase the acetic acid concentration and aerobic stability of silages from several plants species (corn, sorghum, wheat, barley, and grass forages). However, studies related to Bacillus subtilis treatment during the ensiling process are scarce in literature. Todovora and Kozhuharova (2010) reported that B. subtilis produces metabolites with antifungal and antibacterial activity. Phillip and Fellner (1992) evaluated the addition of B. subtilis in corn silage and reported improvements of the aerobic stability.

Chitosan is a biopolymer obtained by the partially deacetylation of chitin, the second most abundant biopolymer in nature, and the major component of crustaceans and insects exoskeleton (Senel and McClure, 2004). The antimicrobial activity of CHI is well known against bacteria and fungi (Senel and McClure, 2004), and have been used as rumen modulator. Chitosan was able to completely inhibit the growth of dimorphic fungus (Olicón-Hernández et al., 2015). Araújo et al. (2015) reported that $\mathrm{CHI}$ quadratically affected the ruminal ammonia nitrogen concentration and the molar proportions of propionate in beef steers. In addition, the same authors found that $\mathrm{CHI}$ increased the digestibility of DM, NDF and crude protein (CP; Araújo et al., 2015).

Our hypothesis was that inoculants would positively affect the fermentation pattern and aerobic stability, decreasing the DM losses of sugarcane silage. Furthermore, CHI would alter microbiology and reduce fungi amounts in the silage. The objective of the current study was to evaluate the effects of three inoculants on chemical composition, DM and NDF in vitro degradation, fermentative and effluent losses, microbiology, fermentative profile, and aerobic stability of sugarcane mini-silos.

\section{Material and methods}

The experiment was conducted between May and September of 2013 at the Department of Animal Science, School of Agrarian Sciences, Federal University of Grande Dourados, Dourados, Brazil; $22^{\circ} 14^{\prime} \mathrm{S}$ latitude, $54^{\circ} 49^{\prime}$ W longitude and $450 \mathrm{~m}$ altitude.

\subsection{Treatments and ensiling}

Sugarcane variety RB 84-5257 was manually harvested from 10 batches within one 0.35 -ha plot after 10 months of regrowth (second cut). Approximately $50.0 \mathrm{~kg}$ of sugarcane tillers from each location was separately chopped in a stationary cutter to a theoretical cut length of $10 \mathrm{~mm}$. A randomized experimental design was used, and contained 4 treatments distributed into $40 \mathrm{mini}$-silos. Mini-silos were produced in plastic bucket ( $30 \mathrm{~cm}$ of height and $30 \mathrm{~cm}$ of diameter) containing Bunsen valves to avoid the gas scape. Two kilograms of sand were placed at the bottom of mini-silos, separated from the forage by a nylon screen to determine the effluent production. Silos were packed $\left(650 \mathrm{~kg} / \mathrm{m}^{3}\right.$, on wet basis), sealed, weighed, and stored at room temperature $\left(28.5 \pm 2.3^{\circ} \mathrm{C}\right)$ for 60 days. Mini-silos were weighed immediately after the opening to record DM and gas losses.

Treatments were randomly distributed to the mini-silos, in which: (1) Control (CON); (2) L. buchneri (Lb), addition of Lb at $2.6 \times 10^{10} \mathrm{cfu} / \mathrm{g}$; (3) L. and B. subtilis ( $\mathrm{Lb}+\mathrm{Bs}$ ), addition of $\mathrm{Lb}$ at $2.6 \times 10^{10} \mathrm{cfu} / \mathrm{g}$ and Bs at $1 \times 10^{9} \mathrm{cfu} / \mathrm{g}$; and (4) Chitosan (CHI), addition of $1 \%$ of $\mathrm{CHI}$ on wet basis of sugarcane ensiled. Chitosan used during all experiment had the technical specifications: apparent density of $0.64 \mathrm{~g} / \mathrm{mL}, 20.0 \mathrm{~g} / \mathrm{kg}$ of ash, 7.0-9.0 of pH, viscosity <200 cPs and deacetylation level of 95\% (Polymar Industria, Ceara, Brazil). In addition, the CHI had $873 \mathrm{~g} / \mathrm{kg}$ of DM and $316 \mathrm{~g} / \mathrm{kg}$ of CP. The treatments $2(\mathrm{Lb})$ and $3(\mathrm{Lb}+\mathrm{Bs})$ were added at $2 \mathrm{~g} / \mathrm{t}$ of natural matter ensiled. Microbial inoculants were diluted in water $(2 \mathrm{~g} / \mathrm{L})$ and sprayed onto the forage, 
Table 1

Chemical composition of sugarcane before the ensiling ( $/ \mathrm{kg}$ DM, otherwise stated).

\begin{tabular}{ll}
\hline Dry matter $(\mathrm{g} / \mathrm{kg})$ & 275 \\
Organic matter & 963 \\
Protein & 28.4 \\
Neutral detergent fiber & 502 \\
Acid detergent fiber & 272 \\
Lignin (sa) & 55.9 \\
Ash & 36.6
\end{tabular}

and $\mathrm{CHI}$ was top dressed and mixed into the fresh forage. The same amount of water was added to the CON and CHI. All inoculants were added separately in each mino-silo.

\subsection{Chemical composition and in vitro degradation}

Prior to the ensiling, sugarcane was sampled and stored at $-20^{\circ} \mathrm{C}$ until chemical analyses. Dry matter (\#950.15), $\mathrm{CP}$ (\#984.13), and ash (\#942.05) were determined according to the procedures of AOAC (2002). Crude protein was calculated as Kjeldal $\mathrm{N} \times 6.25$. Neutral detergent fiber, acid detergent fiber (aADF) and lignin (sa) were determined according to Van Soest et al. (1991). Total digestible nutrient (TDN) was estimated following the equations of NRC (2000). The soluble solid content in the stalk juice was $18.4^{\circ}$ Brix. The chemical composition of sugarcane is shown in Table 1 . At the silos opening, 5 samples $(0.2 \mathrm{~kg})$ of each mini-silo were collected to form a composite sample, and then were analyzed to determine DM, CP, NDF, ADF, lignin (sa), ash and TDN content as previously described. The in vitro degradation of DM and NDF was performed according to Tilley and Terry (1963).

\subsection{Fermentative and effluent losses}

Mini-silos were weighed on days 15, 30, 45 and 60 after the ensiling. On day 60 of ensiling, mini-silo were opened to determine gas losses. The silage, silo assembly, sand layer and nylon screen were weighed to quantify the effluent production. Gas losses were calculated as follows:

$$
\mathrm{GL}=(\mathrm{SWE}-\mathrm{WSO}) / \mathrm{DME} \times 100
$$

in which GL= gas losses (\%DM), SWE = silo weight prior to the ensiling (kg), WSO = silo weight after the mini-silos opening $(\mathrm{kg})$ and $\mathrm{DME}=$ dry matter ensiled $(\mathrm{kg}$ of forage $\times \% \mathrm{DM})$.

Effluent production was calculated according to the equation:

$$
\mathrm{EP}=(\mathrm{WSAO}-\mathrm{WSAE}) / \mathrm{DME} \times 100
$$

in which $\mathrm{EP}=$ effluent production ( $\mathrm{kg}$ of effluent/t of natural matter ensiled), WSAO = weight of the silo assembly after the mini-silos opening $(\mathrm{kg}), \mathrm{WSAE}=$ silo weight before ensiling and DME $=$ dry matter ensiled $(\mathrm{kg}$ of forage $\times \% \mathrm{DM})$.

Dry matter recovery (DMR) was calculated as:

$$
\mathrm{DMR}=(\mathrm{FDM} / \mathrm{IDM}) \times 100
$$

in which FDM = dry matter after the mini-silos opening $(\mathrm{kg})$ and IDM = dry matter before the ensiling.

Changes of DM content were calculated as the difference in module of DM percentage at the ensiling moment and the DM percentage at the mini-silos opening.

\subsection{Microbiology}

Samples $(0.2 \mathrm{~kg})$ were collected on day 60 after the ensiling from five different sites of all mini-silos and homogenized to form a composite sample. Then, subsamples of $10 \mathrm{~g}$ of each treatment were diluted in $90 \mathrm{~mL}$ of sterilized sodium chloride solution $(0.9 \%)$ and a serial dilution was performed from $10^{-1}$ until $10^{-6}$ in test tubes. The microorganism counting was performed in triplicate from each dilution using culture medium of MRS agar (De Man, Rogosa and Sharpe) to lactic-acid bacteria, nutrient agar to aerobic and anaerobic bacteria $\left(48 \mathrm{~h}\right.$ of incubation at $37^{\circ} \mathrm{C}$ ) and agar PDA (potato dextrose agar, $120 \mathrm{~h}$ of incubation at $26^{\circ} \mathrm{C}$ ) for mold and yeast.

\subsection{Fermentative profile}

After the opening of mini-silos (on day 60), sugarcane silage was homogenized and one sample ( $500 \mathrm{~g}$ ) of each bucket was collected, and then the juice from samples was extracted by a hydraulic press. Silage juice aliquots ( $50 \mathrm{~mL})$ were collected to determine $\mathrm{pH}$ using a digital potentiometer. Aliquots of $2 \mathrm{~mL}$ of silage juice were transferred to test tubes containing $1 \mathrm{~mL}$ of sulfuric acid $(1 \mathrm{~N})$ and stored at $-20^{\circ} \mathrm{C}$. Ammonia nitrogen analysis was performed by colorimetric method described by Kulasek (1972) and adapted by Foldager (1977). 
The analyses of short-chain fatty acids, ethanol and acid lactic concentration were carried out at the Department of Animal Nutrition and Production, School of Veterinary Medicine and Animal Science - University of São Paulo, Pirassununga, Brazil, according to the methods described by Rodrigues et al. (2012). Aliquots of $1 \mathrm{~mL}$ of silage juice were mixed with $0.2 \mathrm{~mL}$ formic acid in amber glass bottles and stored at $-18^{\circ} \mathrm{C}$ until analysis. Short-chain fatty acids and ethanol concentrations were determined by a gas chromatograph (Focus GC, Thermo Fisher Scientific Inc., Waltham, MA, USA) equipped with an automatic sample injector (model AS-3000, Thermo Electron Corporation $\left.{ }^{\circledR}, \mathrm{MA}, \mathrm{USA}\right)$, a glass packed column $\left(2.0 \mathrm{~m} \times 1 / 5^{\prime \prime}\right.$, $80 / 120$ Carbopack $^{\circledR}$ B-DA/4\% Carbowax ${ }^{\circledR} 20 \mathrm{M}$ phase) and a flame ionization detector set at $270^{\circ} \mathrm{C}$. The chromatograph oven and injector temperatures were set to $190^{\circ} \mathrm{C}$ and $220^{\circ} \mathrm{C}$, respectively. Hydrogen was used as the carrier gas flowing $30 \mathrm{~mL} / \mathrm{min}$. The acid lactic concentration was measured by high performance liquid chromatography (LC-10ADVP Shimadzu HPLC system, Shimadzu Inc., Kyoto, Japan) according to Ding et al. (1995).

\subsection{Aerobic stability}

Silo temperatures were obtained using an infrared digital thermometer every $8 \mathrm{~h}$ during 7 days after the silos opening. The aerobic stability was defined as the period $(\mathrm{h})$ in which silage remained stable before rising more than $1{ }^{\circ} \mathrm{C}$ above the room temperature (Driehuis et al., 2001). In addition, during the aerobic stability assessment, one mini-silo per treatment was randomly assigned to sample collections every $24 \mathrm{~h}$, to determine DM (AOAC 2002, \#950.15) and pH (Kung et al., 1984).

\subsection{Statistical analyses}

Data related to the silage chemical composition, in vitro degradation, total losses, microbiology, fermentative profile, and aerobic stability period were analyzed by the MIXED procedure of SAS (9.1 version, SAS Institute Cary, NC, 2004) after the normality of residues and homogeneity of variances tested by the UNIVARIATE procedure, using the model below:

$$
Y_{i}=\mu+A_{i}+e_{i}
$$

in which $Y_{i}=$ dependent variable, $\mu=$ overall mean, $A_{i}=$ fixed effect of additive, and $e_{i}=$ residual. Satterthwaite method ( $\mathrm{ddfm}=$ satterth) was applied to calculate degrees of freedom. Microbiological data were log transformed.

Data of DM losses and pH over the aerobic stability were analyzed as repeated measures using the MIXED procedure (SAS 9.1, SAS Institute), and normality of residues and homogeneity of variances were also checked as previously described. The model used was:

$$
Y_{i j}=\mu+A_{i}+T_{j}+A_{i} \times T_{j}+e_{i j}
$$

in which $Y_{i j}=$ dependent variable, $\mu$ =overall mean, $A_{i}=$ fixed effect of additive, $T_{j}=$ random effect of time (hours), $A_{i} \times T_{j}=$ interaction effect of additive by time, and $e_{i j}=$ residual.

Differences among treatments were determined using orthogonal contrasts: $\mathrm{C} 1=$ control versus $\mathrm{Lb}$ and $\mathrm{Lb}+\mathrm{Bs}, \mathrm{C} 2=$ control versus chitosan and $\mathrm{C} 3=$ chitosan versus $\mathrm{Lb}+\mathrm{Bs}$. Significance level was set at 0.05 .

\section{Results}

\subsection{Chemical composition and in vitro degradation}

Microbial inoculants increased $(P=0.001) \mathrm{CP}$ content of sugarcane silage and did not affect in vitro degradation of DM and NDF compared to CON (Table 2). Nevertheless, CHI increased $(P \leq 0.043) \mathrm{DM}, \mathrm{OM}, \mathrm{CP}$ and TDN silage content, and decreased $(P=0.033)$ ash content compared to CON. Chitosan incorporation improved $(P=0.029)$ NDF in vitro degradation. In addition, incorporation of $\mathrm{CHI}$ increased $(P \leq 0.042)$ the DM, OM, CP and TDN content and decreased $(P=0.022)$ the ash content of sugarcane silage compared to silages treated $\mathrm{Lb}$ and $\mathrm{Lb}+\mathrm{Bs}$.

\subsection{Fermentative and effluent losses}

Microbial inoculants decreased $(P \leq 0.004)$ gas $(\%)$ and effluent losses $(\mathrm{kg} / \mathrm{t}$ and $\mathrm{g} / \mathrm{kg} \mathrm{DM})$, and consequently decreased $(P=0.009)$ total losses (Table 3$)$. However, $\mathrm{Lb}$ and $\mathrm{Lb}+\mathrm{Bs}$ did not alter the DMR $(P=0.089)$. Chitosan incorporation ameliorate $(P \leq 0.043)$ the gas, effluent and total losses compared to CON, increasing $(P=0.031)$ the DMR. Chitosan incorporation showed lower $(P \leq 0.035)$ gas and total losses, but increased $(P=0.001)$ the losses by effluent compared to Lb and $\mathrm{Lb}+\mathrm{Bs}$. Furthermore, CHI incorporation showed higher $(P=0.022)$ DMR than microbial inoculants.

\subsection{Microbiology}

The three inoculants increased $(P \leq 0.002)$ the number of lactic-acid and anaerobic bacteria and decreased $(P \leq 0.009)$ aerobic bacteria and fungi in relation to CON (Table 4). Likewise, $\mathrm{CHI}$ incorporation increased $(P \leq 0.003)$ lactic-acid and 
Table 2

Effects of three inoculants on chemical composition and in vitro degradation of sugarcane silage (g/kg DM, otherwise stated).

\begin{tabular}{|c|c|c|c|c|c|c|c|c|}
\hline \multirow[t]{2}{*}{ Item } & \multicolumn{4}{|c|}{ Treatment $^{\mathrm{a}}$} & \multirow[t]{2}{*}{ SEM } & \multicolumn{3}{|l|}{$\mathrm{P}^{\mathrm{b}}$} \\
\hline & $\mathrm{CON}$ & $\mathrm{Lb}$ & $\mathrm{Lb}+\mathrm{Bs}$ & $\mathrm{CHI}$ & & $\mathrm{C} 1$ & $\mathrm{C} 2$ & $\mathrm{C} 3$ \\
\hline \multicolumn{9}{|l|}{ Chemical } \\
\hline Dry matter (g/kg) & 230 & 227 & 221 & 249 & 0.29 & 0.542 & 0.013 & 0.002 \\
\hline Organic matter & 941 & 944 & 945 & 953 & 0.09 & 0.714 & 0.003 & 0.042 \\
\hline Crude protein & 21.8 & 24.1 & 23.2 & 26.5 & 0.04 & 0.001 & 0.001 & 0.001 \\
\hline Neutral detergent fiber & 636 & 642.4 & 659 & 621 & 0.79 & 0.803 & 0.504 & 0.120 \\
\hline Acid detergent fiber & 343 & 349 & 340 & 338 & 0.39 & 0.349 & 0.561 & 0.651 \\
\hline Lignin (sa) & 72.1 & 61.0 & 61.2 & 61.1 & 0.55 & 0.128 & 0.197 & 0.998 \\
\hline Ash & 59.3 & 55.4 & 55.5 & 47.0 & 0.09 & 0.574 & 0.033 & 0.022 \\
\hline Total digestible nutrient ${ }^{\mathrm{C}}$ & 529 & 548 & 553 & 571 & 0.22 & 0.774 & 0.043 & 0.032 \\
\hline \multicolumn{9}{|l|}{ In vitro degradation } \\
\hline Dry matter & 607 & 589 & 592 & 622 & 0.48 & 0.291 & 0.728 & 0.369 \\
\hline Neutral detergent fiber (g/kg NDF) & 623 & 635 & 629 & 669 & 0.37 & 0.350 & 0.029 & 0.496 \\
\hline
\end{tabular}

Table 3

Effects of three inoculants on fermentative and effluent losses of sugarcane silage (g/kg DM, otherwise stated).

\begin{tabular}{|c|c|c|c|c|c|c|c|c|}
\hline \multirow[t]{2}{*}{ Item } & \multicolumn{4}{|c|}{ Treatment $^{\mathrm{a}}$} & \multirow[t]{2}{*}{ SEM } & \multicolumn{3}{|l|}{$\mathrm{P}^{\mathrm{b}}$} \\
\hline & $\mathrm{CON}$ & $\mathrm{Lb}$ & $\mathrm{Lb}+\mathrm{Bs}$ & $\mathrm{CHI}$ & & $\mathrm{C} 1$ & $\mathrm{C} 2$ & $\mathrm{C} 3$ \\
\hline \multicolumn{9}{|l|}{ Losses } \\
\hline Gas losses (\% natural matter) & 2.99 & 2.26 & 2.72 & 2.24 & 0.09 & 0.001 & 0.001 & 0.981 \\
\hline Gas losses & 264 & 207 & 201 & 119 & 0.88 & 0.074 & 0.001 & 0.035 \\
\hline Effluent losses ( $\mathrm{kg} / \mathrm{t}$ natural matter) & 38.9 & 29.9 & 30.5 & 30.9 & 0.99 & 0.003 & 0.043 & 0.760 \\
\hline Effluent losses & 31.8 & 24.3 & 23.0 & 27.8 & 0.08 & 0.004 & 0.001 & 0.001 \\
\hline Total losses & 287 & 226 & 239 & 147 & 0.87 & 0.009 & 0.001 & 0.001 \\
\hline Dry matter recovery & 736 & 799 & 793 & 880 & 0.88 & 0.089 & 0.031 & 0.022 \\
\hline
\end{tabular}

a Control (CON); Lactobacillus buchneri (Lb), addition of Lb at $2.6 \times 10^{10} \mathrm{cfu} / \mathrm{g}$; Lactobacillus buchneri and Bacillus subtilis (Lb $+\mathrm{Bs}$ ), addition of Lb at $2.6 \times 10^{10} \mathrm{cfu} / \mathrm{g}$ and Bs at $1 \times 10^{9} \mathrm{cfu} / \mathrm{g}$; and Chitosan $(\mathrm{CHI})$, addition of $1 \%$ of $\mathrm{CHI}$ on wet basis of sugarcane ensiled.

b Orthogonal contrasts: $\mathrm{C} 1$ : control versus $\mathrm{Lb}$ and $\mathrm{Lb}+\mathrm{Bs}, \mathrm{C} 2$ : control versus chitosan, and $\mathrm{C} 3$ : $\mathrm{Lb}$ and $\mathrm{Lb}+\mathrm{Bs}$ versus chitosan.

Table 4

Effects of three inoculants on microbiology of sugarcane silage.

\begin{tabular}{|c|c|c|c|c|c|c|c|c|}
\hline \multirow[t]{2}{*}{ Item } & \multicolumn{4}{|c|}{ Treatment $^{\mathrm{a}}$} & \multirow[t]{2}{*}{ SEM } & \multicolumn{3}{|l|}{$\mathrm{P}^{\mathrm{b}}$} \\
\hline & CON & $\mathrm{Lb}$ & $\mathrm{Lb}+\mathrm{Bs}$ & $\mathrm{CHI}$ & & $\mathrm{C} 1$ & $\mathrm{C} 2$ & C3 \\
\hline \multicolumn{9}{|c|}{ Bacteria ( $\log _{10} \mathrm{cfu} / \mathrm{g}$ fresh silage) } \\
\hline Lactic-acid & 4.29 & 5.40 & 5.38 & 6.19 & 0.10 & 0.001 & 0.001 & 0.001 \\
\hline Aerobic & 5.38 & 4.56 & 4.30 & 4.53 & 0.07 & 0.004 & 0.031 & 0.435 \\
\hline Anaerobic & 4.25 & 4.92 & 4.97 & 5.77 & 0.11 & 0.002 & 0.003 & 0.760 \\
\hline Total & 5.74 & 5.08 & 5.50 & 5.97 & 0.09 & 0.344 & 0.671 & 0.781 \\
\hline Fungi $\left(\log _{10} / g\right.$ fresh silage $)$ & 6.75 & 5.09 & 4.72 & 5.02 & 0.12 & 0.009 & 0.031 & 0.122 \\
\hline
\end{tabular}

a Control (CON); Lactobacillus buchneri (Lb), addition of Lb at $2.6 \times 10^{10} \mathrm{cfu} / \mathrm{g}$; Lactobacillus buchneri and Bacillus subtilis (Lb $\left.+\mathrm{Bs}\right)$, addition of $\mathrm{Lb}$ at $2.6 \times 10^{10} \mathrm{cfu} / \mathrm{g}$ and Bs at $1 \times 10^{9} \mathrm{cfu} / \mathrm{g}$; and Chitosan $(\mathrm{CHI})$, addition of $1 \%$ of $\mathrm{CHI}$ on wet basis of sugarcane ensiled.

b Orthogonal contrasts: $\mathrm{C} 1$ : control versus $\mathrm{Lb}$ and $\mathrm{Lb}+\mathrm{Bs}, \mathrm{C} 2$ : control versus chitosan, and $\mathrm{C} 3$ : $\mathrm{Lb}$ and $\mathrm{Lb}+\mathrm{Bs}$ versus chitosan.

anaerobic bacteria, and decreased $(P=0.031)$ aerobic bacteria and fungi compared to CON. Furthermore, $\mathrm{CHI}$ incorporation showed higher $(P=0.001)$ number of lactic-acid bacteria than $\mathrm{Lb}$ and $\mathrm{Lb}+\mathrm{Bs}$.

\subsection{Fermentative profile}

All inoculants decreased $(P=0.031) \mathrm{pH}$ and increased $(P=0.002)$ ammonia nitrogen compared to CON (Table 5). Sugarcane silages treated with inoculants showed higher $(P \leq 0.034)$ concentrations of acetate, butyrate and lactic acid than CON. In addition, inoculants decreased $(P \leq 0.004)$ ethanol concentrations compared to CON. Although $\mathrm{CHI}$ incorporation showed lower $(P \leq 0.034) \mathrm{pH}$ and ethanol concentration, and higher $(P=0.001)$ acetate, butyrate and lactic acid concentrations than CON, CHI strongly increased $(P=0.001,294.9 \%)$ the $\mathrm{NH}_{3}-\mathrm{N}$ concentration in mini-silos. Chitosan incorporation also showed higher $(P \leq 0.003) \mathrm{NH}_{3}-\mathrm{N}$ and butyrate concentrations compared to the silages treated with $\mathrm{Lb}$ and $\mathrm{Lb}+\mathrm{Bs}$. Furthermore, $\mathrm{CHI}$ incorporation demonstrated lower $(P=0.002)$ ethanol concentration in silage than $\mathrm{Lb}$ and $\mathrm{Lb}+\mathrm{Bs}$. 
Table 5

Effects of three inoculants on fermentative profile of sugarcane silage.

\begin{tabular}{|c|c|c|c|c|c|c|c|c|}
\hline \multirow[t]{2}{*}{ Item } & \multicolumn{4}{|c|}{ Treatment $^{\mathrm{a}}$} & \multirow[t]{2}{*}{ SEM } & \multicolumn{3}{|l|}{$\mathrm{P}^{\mathrm{b}}$} \\
\hline & $\mathrm{CON}$ & $\mathrm{Lb}$ & $\mathrm{Lb}+\mathrm{Bs}$ & $\mathrm{CHI}$ & & $\mathrm{C} 1$ & $\mathrm{C} 2$ & $\mathrm{C} 3$ \\
\hline $\mathrm{pH}$ & 4.22 & 3.33 & 3.34 & 3.32 & 0.01 & 0.031 & 0.034 & 0.981 \\
\hline $\mathrm{NH}_{3}-\mathrm{N}(\mathrm{mg} / \mathrm{dL})$ & 5.47 & 5.68 & 7.15 & 16.13 & 0.79 & 0.002 & 0.001 & 0.002 \\
\hline Acetate (g/kg DM) & 5.24 & 5.07 & 6.73 & 8.02 & 0.01 & 0.004 & 0.001 & 0.345 \\
\hline Propionate (g/kg DM) & 1.2 & 0.9 & 3.1 & 1.2 & 0.03 & 0.872 & 0.563 & 0.785 \\
\hline Butyrate (g/kg DM) & 4.2 & 7.5 & 3.1 & 6.3 & 0.03 & 0.034 & 0.001 & 0.003 \\
\hline Ethanol (g/kg DM) & 33.9 & 23.7 & 20.8 & 11.3 & 0.14 & 0.004 & 0.001 & 0.002 \\
\hline Lactic acid (g/kg DM) & 33.4 & 50.3 & 56.5 & 67.8 & 0.23 & 0.003 & 0.001 & 0.289 \\
\hline
\end{tabular}

a Control (CON); Lactobacillus buchneri (Lb), addition of Lb at $2.6 \times 10^{10} \mathrm{cfu} / \mathrm{g}$; Lactobacillus buchneri and Bacillus subtilis (Lb $+\mathrm{Bs}$ ), addition of Lb at $2.6 \times 10^{10} \mathrm{cfu} / \mathrm{g}$ and Bs at $1 \times 10^{9} \mathrm{cfu} / \mathrm{g}$; and Chitosan $(\mathrm{CHI})$, addition of $1 \%$ of $\mathrm{CHI}$ on wet basis of sugarcane ensiled.

b Orthogonal contrasts: C1: control versus Lb and Lb + Bs, C2: control versus chitosan, and C3: Lb and Lb + Bs versus chitosan.

\section{Table 6}

Effects of three inoculants on 7-day aerobic stability of sugarcane silage.

\begin{tabular}{|c|c|c|c|c|c|c|c|c|}
\hline \multirow[t]{2}{*}{ Item } & \multicolumn{4}{|c|}{ Treatment $^{\mathrm{a}}$} & \multirow[t]{2}{*}{ SEM } & \multicolumn{3}{|l|}{$\mathrm{P}^{\mathrm{b}}$} \\
\hline & CON & $\mathrm{Lb}$ & $\mathrm{Lb}+\mathrm{Bs}$ & $\mathrm{CHI}$ & & $\mathrm{C} 1$ & $\mathrm{C} 2$ & C3 \\
\hline Aerobic stability (h) & 32.00 & 43.20 & 41.60 & 49.6 & 2.48 & 0.026 & 0.013 & 0.224 \\
\hline $\mathrm{pH}$ & 5.86 & 5.74 & 5.53 & 6.08 & 0.11 & 0.233 & 0.132 & 0.045 \\
\hline Dry matter losses $(\mathrm{g} / \mathrm{kg})$ & 311 & 293 & 254 & 299 & 0.38 & 0.123 & 0.654 & 0.034 \\
\hline
\end{tabular}

a Control (CON); Lactobacillus buchneri (Lb), addition of Lb at $2.6 \times 10^{10} \mathrm{cfu} / \mathrm{g}$; Lactobacillus buchneri and Bacillus subtilis (Lb $+\mathrm{Bs}$ ), addition of Lb at $2.6 \times 10^{10} \mathrm{cfu} / \mathrm{g}$ and Bs at $1 \times 10^{9} \mathrm{cfu} / \mathrm{g}$; and Chitosan $(\mathrm{CHI})$, addition of $1 \%$ of $\mathrm{CHI}$ on wet basis of sugarcane ensiled.

b Orthogonal contrasts: $\mathrm{C} 1$ : control versus $\mathrm{Lb}$ and $\mathrm{Lb}+\mathrm{Bs}, \mathrm{C} 2$ : control versus chitosan, and $\mathrm{C} 3$ : Lb and $\mathrm{Lb}+\mathrm{Bs}$ versus chitosan.

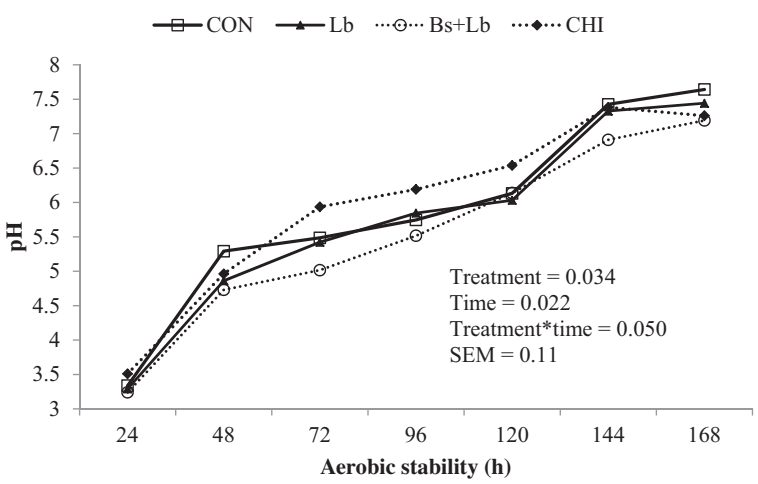

Fig. 1. pH values of sugarcane silage treated with three inoculants during aerobic stability assessment. Control (CON); Lactobacillus buchneri (Lb), addition of $\mathrm{Lb}$ at $2.6 \times 10^{10} \mathrm{cfu} / \mathrm{g}$; Lactobacillus buchneri and Bacillus subtilis $(\mathrm{Lb}+\mathrm{Bs})$, addition of $\mathrm{Lb}$ at $2.6 \times 10^{10} \mathrm{cfu} / \mathrm{g}$ and $\mathrm{Bs}$ at $1 \times 10^{9} \mathrm{cfu} / \mathrm{g}$; and Chitosan $(\mathrm{CHI})$, addition of $1 \%$ of $\mathrm{CHI}$ on wet basis of sugarcane ensiled.

\subsection{Aerobic stability}

Inoculants decreased $(P=0.010$ ) silo stability temperatures (Table 6). Moreover, the period of aerobic stability was higher $(P=0.026)$ in silages treated with inoculants compared to CON. Chitosan incorporation decreased $(P=0.004)$ the temperature of stability in mini-silos and prolonged $(P=0.013)$ the period of aerobic stability of sugarcane silage. Chitosan incorporation showed higher $(P \leq 0.045) \mathrm{pH}$ and $\mathrm{DM}$ losses than silages treated $\mathrm{Lb}$ and $\mathrm{Lb}+\mathrm{Bs}$. The average $\mathrm{pH}$ values after $24 \mathrm{~h}$ of silos opening was 3-3.5 and progressively increased until 6.5-7.2 (Fig. 1). Dry matter content of sugarcane silage showed effects of time, treatment and treatment by time interaction (Fig. 2).

\section{Discussion}

Despite the potential of sugarcane as a forage source along drought periods, sugarcane silages are characterized by high DM losses, ethanol production and yeast activity. The current experiment showed that CHI ameliorated DM losses, and consequently increased the DM content of sugarcane silage. However, the increased DM content of sugarcane silage may be related to the DM content of $\mathrm{CHI}$ added to the sugarcane, which may also influenced the effluent and fermentation losses. The absence of $L$. bucheneri effects on DM sugarcane silage content have been reported in several studies (Ávila et al., 2009; Santos et al., 2009). In addition, B. subtilis did not affect DM content of sugarcane silage (Basso et al., 2012). 


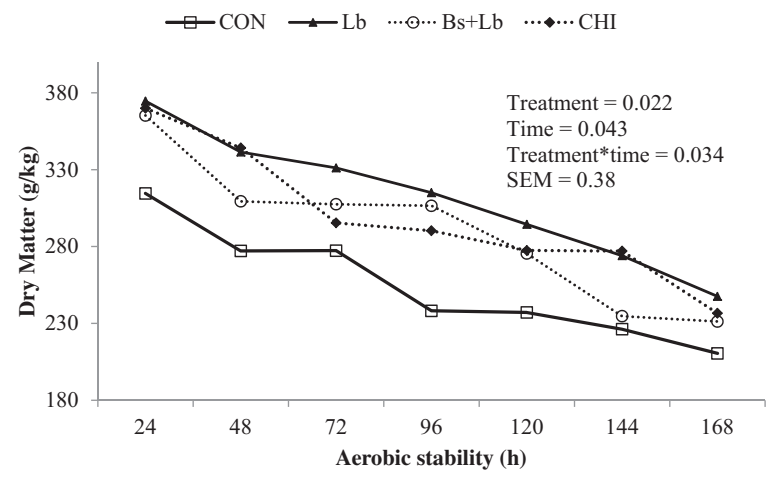

Fig. 2. Dry matter content of sugarcane silage treated with three inoculants during the aerobic stability assessment. Control (CON); Lactobacillus buchneri (Lb), addition of $\mathrm{Lb}$ at $2.6 \times 10^{10} \mathrm{cfu} / \mathrm{g}$; Lactobacillus buchneri and Bacillus subtilis ( $\left.\mathrm{Lb}+\mathrm{Bs}\right)$, addition of $\mathrm{Lb}$ at $2.6 \times 10^{10} \mathrm{cfu} / \mathrm{g}$ and $\mathrm{Bs}$ at $1 \times 10^{9} \mathrm{cfu} / \mathrm{g}$; and Chitosan (CHI), addition of $1 \%$ of $\mathrm{CHI}$ on wet basis of sugarcane ensiled.

Incorporation of $\mathrm{CHI}$ increased the DM content of sugarcane silage due to the lower gas and effluent losses, and higher DMR than CON. The effluent release during the ensiling process represents a loss of DM and a reduction of the nutritional value of silage (Gabrehanna et al., 2014). Despite all additives diminished the effluent losses, the chemical composition of sugarcane silage was not extensively altered by microbial inoculants. The DM losses of sugarcane silage is mainly from $\mathrm{CO}_{2}$ production by the fermentation pathway which yields ethanol, that may represents up to $54 \%$ of total DM losses of sugarcane silage (Pedroso et al., 2005). To our knowledge, there is no study evaluating CHI as additive in silages. Interestingly, CHI decreased the silage ethanol concentrations and fungi activity. The ethanol production in sugarcane silage is raised from fermentation of water-soluble sugars catalyzed by yeasts (Kung et al., 2003). The antifungal effect of CHI is related to the capacity of suppressing sporulation and spore germination (Hernandez-Lauzardo et al., 2008), and may be even greater in sugarcane silages compared to other crops, because CHI antifungal activity is increased at lower pH values (Roller and Covill, 1992). Finally, we highlight that the association of $\mathrm{Lb}+\mathrm{Bs}$ showed the lowest value of fungi concentration in silage. Chitarra et al. (2003) reported that strains of $B$. subtilis are able to produce antifungal compounds which block the spore germination; and Basso et al. (2012) reported a linear decrease of spoilage microorganisms concentration in maize silage treated B. subtilis, due to its antifungal activity (Todovora and Kozhuharova, 2009).

The current study showed an increase of NDF degradation when adding $\mathrm{CHI}$ to sugarcane silage, but the reason is not clear. Several studies reported stronger antibacterial activity against Gram-negative bacteria than Gram-positive bacteria (Chung et al., 2004; No et al., 2002). Lactic acid bacteria are gram-positive and their metabolic activity is important to silage quality (Duniere et al., 2013). In general, lactic acid is the goal of end product of fermentation in the silo, due to lactic acid be a stronger acid $\left(\mathrm{pK}_{\mathrm{a}} 3.86\right)$ than acetic $\left(\mathrm{pK}_{\mathrm{a}} 4.76\right.$; Muck, 2010). High concentrations of lactic acid can rapidly drop the silage $\mathrm{pH}$, and reduce the activity of spoilage microorganisms and production of butyric acid. Weinberg et al. (2007) ensiled corn and wheat forages with lactic acid bacteria and reported improve of the in vitro NDF degradation of forages. In addition, Nsereko et al. (2008) demonstrated that several lactic acid bacteria produce ferulic acid esterase in the silo, which has the potential to improve fiber degradation.

All additives decreased the $\mathrm{pH}$ of sugarcane silage, because they increased the acetate, propionate and lactic organic acids in mini-silos. Kleinschmidt and Kung (2006) evaluated 43 studies that inoculated $L$. buchneri in different forages to ensilage (corn, sorghum, barley and grasses) and reported that microbial inoculant decreased pH and improved the aerobic stability of silages. Data of pH values of $\mathrm{CHI}$ and Bs as additives for silages are scarce in literature. Meanwhile inoculants decreased the silage $\mathrm{pH}$, they increased the silage ammonia nitrogen concentration. Increased concentrations of ammonia, as well as, the increased butyrate production, are not expected once ammonia is related to excessive protein breakdown caused by a slow drop in $\mathrm{pH}$, and the butyrate production is related to yeast activity. The highest values of ammonia concentrations when $\mathrm{CHI}$ was incorporated to the silages may be related to the $\mathrm{CP}$ of chitin (precursor of $\mathrm{CHI}$ ) that may reach $10.8 \%$ (Manni et al., 2010). In addition, $\mathrm{CHI}$ is a weak base soluble in aqueous acid solution below its $\mathrm{pK}_{\mathrm{a}}(6.3)$, in which glucosamine units $\left(-\mathrm{NH}_{2}\right)$ are converted into soluble protonated form $\left(-\mathrm{NH}_{3}^{+}\right.$; Goy et al., 2009).

Heinl et al. (2012) reported that Lb metabolism can turn lactic acid into acetic acid under an anaerobic environment. Despite $L$. buchneri have been reported to strongly decrease the $\mathrm{pH}$ and increase the acetate concentrations in crimped wheat grains (Adesogan et al., 2003), the acetate production values were increased when $\mathrm{Lb}+\mathrm{Bs}$ were added or when CHI was incorporated into the sugarcane. In contrast, Basso et al. (2012) did not observe differences in production of acetic and lactic acid when corn silage was inoculated with $B$. subtilis. The acetate is the major organic acid to prevent the growth of spoilage microorganisms (Danner et al., 2003; Kleinschmidt and Kung, 2006).

Aerobic deterioration occurs when fermentation products of the silo (i.e. lactic acid) became substrate to microbial growth (Pahlow et al., 2003). Microbial organisms oxidize acids and water-soluble carbohydrates to $\mathrm{CO}_{2}$ and water, resulting in an increase of silo temperature that rises above the ambient temperature (Ranjit and Kung, 2000). The current experiment showed that both microbial inoculants and $\mathrm{CHI}$ were effective to decrease the temperature in which silo reached the stability 
and increased the length of aerobic stability period. Chitosan treated silages had higher pH and DM losses than microbial inoculants. However, the higher DM losses of CHI may be related to its chemical composition, since the incorporation of CHI increased the DM and TDN content of sugarcane silage. If more substrate is available to microbial growth, higher DM loss occurs. In a meta-analysis, Kleinschmidt and Kung (2006) reported that the length period of aerobic stability was increased when corn and small-grain silages were treated with $L$. buchneri. Besides the alterations in organic acids production, $L$. buchneri may produce antimicrobial substances that are responsible to enhance aerobic stability, including bacteriocins (Yildirim, 2001).

Finally, $\mathrm{CHI}$ is the second most abundant biopolymer in nature, is a byproduct of marine bioprocessing plants, and has proved environmentally attractive and economically feasible (Avanitoyannis and Kassaveti, 2008). Furthermore, CHI have shown positive effects on nutrient total tract digestion, ruminal fermentation and milk yield in cattle (Araújo et al., 2015; Vendramini et al., 2016; Paiva et al., 2016). Thus, adding CHI to silages may have also positive effects besides those found during the ensiling process.

\section{Conclusion}

Both $\mathrm{CHI}$ and microbial inoculants improved the chemical composition of sugarcane silage. However, $\mathrm{CHI}$ incorporation to the sugarcane showed higher DM and TDN concentrations compared to inoculants treatment. In addition, $\mathrm{CHI}$ increased in vitro degradation of NDF, which was not observed in silages treated with microbial inoculants. Moreover, CHI showed higher concentrations of lactic acid bacteria and lower ethanol concentration than silages treated with microbial inoculants. Furthermore, $\mathrm{CHI}$ improved the aerobic stability compared to CON. Chitosan may be an alternative to microbial inoculants used in sugarcane ensiling.

\section{Conflicts of interest}

The authors declare no conflicts of interest related to this publication and there has been no financial support to the present study that could have influenced its outcome.

\section{Acknowledgment}

Authors acknowledge BIOMART (Biocampo, Nutricao Animal Imp. e Exp. LTDA, Presidente Prudente, Brazil) for microbial inoculants donation.

\section{References}

Ávila, C.L.S., Pinto, J.C., Figueiredo, H.C.P., Schwan, R.F., 2009. Effects of an indigenous and a commercial Lactobacillus buchneri strain on quality of sugar cane silage. Grass Forage Sci. 64, 384-394, http://dx.doi.org/10.1111/j.1365-2494.2009.00703.x.

Association of official Analytical Chemists (AOAC), 2002. Official Methods of Analysis, 17th ed. AOAC International, Arlington, VA.

Adesogan, A., Salawu, M., Ross, A., Davies, D., Brooks, A., 2003. Effect of Lactobacillus buchneri, Lactobacillus fermentum, Leuconostoc mesenteroides inoculants, or a chemical additive on the fermentation, aerobic stability, and nutritive value of crimped wheat grains. J. Dairy Sci. 86, 1789-1796, http://dx.doi.org/10.3168/jds.S0022-0302(03)73764-3.

Araújo, A.P.A., Venturelli, B.C., Santos, M.C.B., Gardinal, R., Cônsolo, N.R.B., Calomeni, G.D., Freitas, J.E., Barletta, R.V., Gandra, J.R., Paiva, P.G., Rennó, F.P., 2015. Chitosan affects total nutrient digestion and ruminal fermentation in Nellore steers. Anim. Feed Sci. Technol. 206, 114-118, http://dx.doi.org/10.1016/j.anifeedsci.2015.05.016.

Avanitoyannis, I.S., Kassaveti, A., 2008. Fish industry waste: treatments, environmental impacts, current and potential uses. Int. J. Food Sci. Technol. 43, 726-745, http://dx.doi.org/10.1111/j.1365-2621.2006.01513.x.

Basso, F.C., Lara, E.C., Assis, F.B., Rabelo, C.H.S., Morelli, M., Reis, R.A., 2012. Fermentation characteristic and aerobic stability of corn silages inoculated with Bacillus subtilis. Rev. Bras. Saúde Prod. Anim. 13, 1009-1019, http://dx.doi.org/10.1590/S1519-99402012000400003.

Carvalho, B.F., Ávilla, C.L.S., Pinto, J.C., Pereira, M.N., Schwan, R.F., 2012. Effects of propionic acid and Lactobacillus buchneri (UFLA SIL 72) addition on fermentative and microbiological characteristics of sugar cane silage treat with and without calcium oxide. Grass Forage Sci. 67, 463-471, http://dx.doi.org/10.1111/j.1365-2494.2012.00863.x.

Chitarra, G.S., Breeuwer, P., Nout, M.J.R., van Aelst, A.C., Rombouts, F.M., Abee, T., 2003. An antifungal compound produced by Bacillus subtilis YM 10-20 inhibits germination of Penicillium roqueforti conidiospores. J. Appl. Microbiol. 94, 159-166, http://dx.doi.org/10.1046/j.1365-2672.2003.01819.x.

Chung, Y.C., Su, Y.P., Chen, C.C., Jia, G., Wang, H.L., Wu, J.C.G., Lin, J.G., 2004. Relationship between antibacterial activity of chitosans and surface characteristics of cell wall. Acta Pharmacol. Sin. 25, 932-936 (no available doi).

Danner, H., Holzer, M., Mayrhuber, E., Braun, R., 2003. Acetic acid increases stability of silage under aerobic conditions. App. Environ. Microbiol. 69, 562-567, http://dx.doi.org/10.1128/AEM.69.1.562-567.2003.

Ding, M.Y., Koizumi, H., Suzuki, Y., 1995. Comparison of three chromatographic systems for determination of organic acids in wine. Anal. Sci. 2, 239-243, http://dx.doi.org/10.2116/analsci.11.239.

Driehuis, F., Oude Elferink, S.J.W.H., Van Wikselaar, P.G., 2001. Fermentation characteristics and aerobic stability of grass silage inoculated with Lactobacillus buchneri, with or without homofermentative lactic acid bacteria. Grass Forage Sci. 56, 330-343, http://dx.doi.org/10.1046/j.1365-2494.2001.00282.x.

Duniere, L., Sindou, J., Chaucheyras-Durand, F., Chevallier, I., Thevenot-Sergentet, D., 2013. Silage processing and strategies to prevent persistence of undesirable microorganisms. Anim. Feed Sci. Technol. 182, 1-15, http://dx.doi.org/10.1016/j.anifeedsci.2014.09.024.

Foldager, J., 1977. Protein requirement and non-protein nitrogen for high producing cow in early lactation. In: PhD Diss. Michigan State University, East Lasing, MI.

Freitas, A.W.P., Pereira, J.C., Rocha, F.C., Costa, M.G., Leonel, F.P., Ribeiro, M.D., 2006. Evaluation of the nutritional quality of sugarcane silage treated with microbial additives and soybean crop residue. R. Bras. Zootec. 35, 38-47, http://dx.doi.org/10.1590/S1516-35982006000100005.

Gabrehanna, M.M., Gordon, R.J., Madani, A., VanderZaag, A.C., Wood, J.D., 2014. Silage effluent management: a review. J. Environ. Manag. 143, 113-122, http://dx.doi.org/10.1016/j.jenvman.2014.04.012. 
Goy, R.C., Britto, D., Assis, O.C.G., 2009. A review of the antimicrobial activity of chitosan. Polímeros 19, 241-247, http://dx.doi.org/10.1590/S0104-14282009000300013.

Heinl, S., Wibberg, D., Eikmeyer, F., Szczepanowski, R., Blom, J., Linke, B., Goesmann, A., Grabherr, T., Schawab, H., Pühler, A., Schlüter, A., 2012. Insights into the completely annotated genome of Lactobacillus buchneri CD034, a strain isolated from stable grass silage. J. Biotechnol. 161, 153-166, http://dx.doi.org/10.1016/j.jbiotec.2012.03.007.

Hernandez-Lauzardo, A.N., Bautista-Banos, S., Velzasquel-del Valle, M.G., Mendez-Montealvo, M.G., Sanhchez-Rivera, M.M., Bello-Perez, L.A., 2008. Antifungal effects of chitosan with different molecular weight on in vitro development of Rhizopus stolonifera (Enrenb.:Fr.) Vuill. Carbohyd. Polym. 73, 541-547, http://dx.doi.org/10.1016/j.carbpol.2007.12.020.

Kleinschmidt, D.H., Kung Jr., L., 2006. A meta-analysis of the effects of Lactobacillus buchneri on the fermentation and aerobic stability of corn and grass and small-grain silages. J. Dairy Sci. 89, 4005-4013, http://dx.doi.org/10.3168/jds.S0022-0302(06) 72444-4.

Kulasek, G.A., 1972. A micromethod for determination of urea in plasma, whole blood and blood cells using urease and phenol reagent. Pol. Arch. Wet. 15, 801-810 (no doi) - http://www.ncbi.nlm.nih.gov/pubmed/4663270?dopt=.

Kung Jr., L., Stanley, R.W., 1982. Effect of stage of maturity on the nutritive value of whole-plant sugarcane preserved as silage. J. Ani. Sci. 54, 689-696, http://dx.doi.org/10.2134/jas1982.544689x.

Kung Jr., L., Grieve, D.B., Thomas, J.W., Huber, J.T., 1984. Added ammonia or microbial inocula for fermentation and nitrogenous compound of alfalfa ensiled at various percents of dry matter. J. Dairy Sci. 67, 299-306, http://dx.doi.org/10.3168/jds.S0022-0302(84)81302-8.

Kung Jr., L., Strokes, M.R., Lin, C.J., 2003. Silage Additives. American Society of Agronomy, Madison, pp. 305-360.

Manni, L., Ghorbel-Bellaaj, O., Jellouli, K., Younes, I., Nasri, M., 2010. Extraction and characterization of chitin, chitosan, and protein hydrolysates prepated from shrimp waste by treatment with crude protease from Bacillus cereus SV1. Appl. Biochem. Biotehnol. 162, 345-357, http://dx.doi.org/10.1007/s12010-009-8846-y.

Muck, R.E., 2010. Silage microbiology and its control through additives. R. Bras. Zootec. 39, 183-191, http://dx.doi.org/10.1590/S1516-35982010001300021.

NRC National Research Council, 2000. Nutrient Requirements of Beef Cattle, 7th ed. National Academics Press, Washington, DC.

No, H.K., Park, N.Y., Lee, S.H., Meyers, S.P., 2002. Antibacterial activity of chitosans and chitosan oligomers with different molecular weights. Int. J. Food Microbiol. 74, 65-72, http://dx.doi.org/10.1016/S0168-1605(01) 00717-6.

Nsereko, V.L., Smiley, B.K., Rutherford, W.M., Spielbauer, A., Forrester, K.J., Hettinger, H.G., Harman, E.K., Harman, B.R., 2008. Influence of inoculating forage with lactic acid bacterial strains that produce ferulate esterase on ensilage and ruminal degradation of fiber. Anim. Feed Sci. Technol. 145, 122-135, http://dx.doi.org/10.1016/j.anifeedsci.2007.06.039.

Olicón-Hernández, D.R., Hernández-Lauzardo, A.N., Pardo, J.P., Peña, A., Velázquez-del Valle, M.G., Guerra-Sánchezm, G., 2015. Influence of chitosan and its derivatives on cell development and physiology of Ustilago maydis. Int. J. Biol. Macromol. 79, 654-660, http://dx.doi.org/10.1016/j.ijbiomac.2015.05.057.

Pahlow, G., Muck, R.E., Driehuis, F., Oude Elferink, S.J.W.H., Spoelstra, S.F., 2003. Microbiology of ensiling. In: Buxton, D.R., Muck, R.E., Harrison, J.H. (Eds.), Silage Science and Technology. American Society of Agronomy, Madison, WI.

Paiva, P.G., Jesus, E.F., Valle, T.A., Almeida, G.F., Costa, A.G.B.V.B., Consentini, C.E.C., Zanferari, F., Takiya, C.S., Bueno, I.C.S., Renno, F.P., 2016. Effects of chitosan on ruminal fermentation, nutrient digestibility, and milk yield and composition of dairy cows. Anim. Prod. Sci., http://dx.doi.org/10.1071/AN15329 (online early view).

Pedroso, A.F., Nussio, L.G., Paziani, S.F., Loures, D.R.S., Igarasi, M.S., Coelo, R.M., Packer, I.H., Horii, J., Gomes, L.H., 2005. Fermentation and epiphytic microflora dynamics in sugar cane silage. Sci. Agric. 62, http://dx.doi.org/10.1590/S0103-90162005000500003 (online version).

Pedroso, A.F., Nussio, L.G., Loures, D.R.S., Paziani, S.F., Ribeiro, J.L., Mari, L.J., Zopollatto, M., Schmidt, P., Mattos, W.R.S., Hori, J., 2008. Fermentation, losses and aerobic stability of sugarcane silages treated with chemical or bacterial additives. Sci. Agric. 65, 589-594, http://dx.doi.org/10.1590/S0103-90162008000600004.

Pedroso, A.F., Nussio, L.G., Rodrigues, A.A., Santos, F.A.P., Mourão, G.B., Barioni Júnior, W., 2010. Performance of dairy cows fed rations produced with sugarcane silages treated with additives or fresh sugarcane. R. Bras. Zootec. 39, 1889-1893, http://dx.doi.org/10.1590/S1516-35982010000900005.

Phillip, L.E., Fellner, V., 1992. Effects of bacterial inoculation of high-moisture ear corn on its aerobic stability, digestion, and utilization for growth by beef steers. J. Ani. Sci. 70, 3178-3187 (no doi) - http://www.ncbi.nlm.nih.gov/pubmed/1429293.

Rodrigues, P.H.M., Gomes, R.C.G., Meyer, P.M., Borgatti, L.M.O., Franco, F.M.J., Godoy, G.L.A., 2012. Effects of microbial inoculants and amino acid production by-product on fermentation and chemical composition of sugarcane silage. R. Bras. Zootec. 41, 1394-1400, http://dx.doi.org/10.1590/S1516-35982012000600011.

Roller, S., Covill, N., 1992. The antifungal properties of chitosan in laboratory media and apple juice. Int. J. Food Microbiol. 47, 67-77, http://dx.doi.org/10.1016/S0168-1605(99) 00006-9.

Santos, M.C., Nussio, L.G., Mourão, G.B., Schmidt, P., Mari, L.J., Ribeiro, J.L., Queiroz, O.C.M., Zopollatto, M., Sousa, D.P., Saturi, J.O., Toledo Filho, S.G., 2009. Nutritive value of sugarcane silage treated with chemical additives. Sci. Agric. 66, 159-163, http://dx.doi.org/10.1590/S0103-90162009000200003.

Santos, W.C.C., Nascimento, W.G., Magalhães, A.L.R., Silva, D.K.A., Silva, W.J.C.S., Santana, A.V.S., Soares, G.S.C., 2015. Nutritive value, total losses of dry matter and aerobic stability of the silage from three varieties of sugarcane treated with comercial microbial additives. Anim. Feed Sci. Technol. 204, 1-8, http://dx.doi.org/10.1016/j.anifeedsci.2015.03.004.

Senel, S., McClure, S.J., 2004. Potential applications of chitosan in veterinary medicine. Adv. Drug. Deliv. Rev. 56, 1467-1480, http://dx.doi.org/10.1016/j.addr.2004.02.007.

Tilley, J.M.A., Terry, R.A., 1963. A two-stage technique for the in vitro digestion of forage crops. Grass Forage Sci. 18, 104-111, http://dx.doi.org/10.1111/j.1365-2494.1963.tb00335.x.

Todovora, S., Kozhuharova, L., 2009. Characteristics and antimicrobial activity of Bacillus subtilis strains isolated from soil. J. Microbio. Biotechnol. 96, 1151-1161, http://dx.doi.org/10.1007/s11274-009-0290-1.

Todovora, S., Kozhuharova, L., 2010. Characteristics and antimicrobial activity of Bacillus subtilis strains isolated from soil. World J. Microbiol. Biotechnol. 26, 1207-1216, http://dx.doi.org/10.1007/s11274-009-0290-1.

Van Soest, P.J., Robertson, J.B., Lewis, B.A., 1991. Methods for dietary fiber, neutral detergent fiber, non-starch polysaccharides in relation to animal nutrition. J. Dairy Sci. 74, 3583-3597, http://dx.doi.org/10.3168/jds.S0022-0302(91) 78551-2.

Vendramini, T.H.A., Takiya, C.S., Silva, T.H., Zanferari, F., Rentas, M.F., Bertoni, J.C., Consentini, C.E.C., Gardinal, R., Acedo, T.S., Rennó, F.P., 2016. Effects of a blend of essentials oils, chitosan or monensin on nutrient intake and digestibility of lactating dairy cows. Ani. Feed Sci. Technol. http://dx.doi.org/10.1016/j.anifeedsci.2016.01.015 (in press).

Weinberg, Z.G., Shatz, O., Chen, Y., Yosef, E., Nikbahat, M., Ben-Ghedalia, D., Miron, J., 2007. Effect of lactic acid bacteria inoculants on in vitro digestibility of wheat and corn silages. J. Dairy Sci. 90, 4754-4762, http://dx.doi.org/10.3168/jds.2007-0176.

Yildirim, M., 2001. Purification of buchnericin LB produced by Lactobacillus buchneri LB. J. Biol. 25, 59-65 (no doi available) 